\title{
Dabrafenib in BRAFV600E mutant pilocytic astrocytoma
}

\section{Sora Yasri ${ }^{1} \cdot$ Viroj Wiwanitkit ${ }^{2}$}

Received: 20 January 2020 / Accepted: 25 January 2020 / Published online: 30 January 2020

(C) Springer-Verlag GmbH Germany, part of Springer Nature 2020

Dear Editor:

We read the report on "Dabrafenib in BRAFV600E mutant pilocytic astrocytoma (PA) in a pediatric patient" with a great interest [1]. Mustansir et al. concluded that "We report a case of successful treatment of BRAFV600E immunopositive optic pathway PA in a child with dabrafenib [1]." In fact, the good clinical advantage of dabrafenib for treatment of BRAFV600E immunopositive optic pathway PA is mentioned in many reports in clinical oncology. The basic molecular change due to BRAFV600E mutation can result in altered phenotypic expression including the response to treatment. Based on standard molecular calculation technique as used in referencing publications $[2,3]$, the molecular weight in BRAFV600E mutation is equal to $-28 \mathrm{~g} / \mathrm{Mol}$ (from to 117.1 to $89.1 \mathrm{~g} / \mathrm{Mol}$ in $\mathrm{V}$ to A variant). Nevertheless, there are also other genetic factors that can determine the response to dabrafenib. In addition to studied genetic background of the tumor, some genetic polymorphisms of the patient might be associated with PA treatment. The good examples are TP53 codon 72 polymorphisms [4, 5]. Further studies to clarify possible confounding effects from other genetic factors are recommended.

Sora Yasri

sorayasri@outlook.co.th

KMT Primary Care Center, Bangkok, Thailand

2 DY Patil University, Pune, India

\section{Compliance with ethical standards}

Conflict of interest None.

\section{References}

1. Mustansir F, Mushtaq N, Darbar A (2020) Dabrafenib in BRAFV600E mutant pilocytic astrocytoma in a pediatric patient. Childs Nerv Syst 36:203-207. https://doi.org/10.1007/s00381-019-04346-2

2. Joob S, Guran M (2019) Letter to editor: G12V and G12C mutations in the gene KRAS and association with prognosis in primary colorectal cancer. Adv Lab Med Int. 9:28-30

3. Joob S, Guran M (2019) PRDM1 rs1010273 polymorphism and survival of patients with hepatitis B virus-related hepatocellular carcinoma. Adv Lab Med Int 9:31-32

4. Mascelli S, Nozza P, Jones DT, Colin C, Pistorio A, Milanaccio C, Ravegnani M, Consales A, Witt O, Morana G, Cama A, Capra V, Biassoni R, Pfister SM, Figarella-Branger D, Garrè ML, Raso A (2016 Jul 26) TP53 codon 72 polymorphism may predict early tumour progression in paediatric pilocytic astrocytoma. Oncotarget. 7(30):47918-47926

5. Guo X, Zhang M, Li Q, Zhao J, Wang B, Wang J, Mao P, Song J (2020 Jan) Evaluation of genetic variants in MIR3142HG in susceptibility to and prognosis of glioma. Am J Clin Oncol 43(1):1-8

Publisher's note Springer Nature remains neutral with regard to jurisdictional claims in published maps and institutional affiliations. 